\title{
THE EFFECT OF THE WAGNER ACT ON INDUSTRIAL RELATIONS
}

\author{
C. E. FRENCH*
}

Commentators on the Wagner Act have been so concerned with the legal aspects of the measure that certain other extremely significant angles have received far too little attention. Persons interested in industrial relations are beginning to realize that for every company which has altered its collective bargaining machinery on account of the law there undoubtedly are several that have revised other features of personnel procedure. Labor policies are being formulated and announced; hiring methods, layoff and discharge techniques, and the basis of promotion are receiving critical attention; supervisory groups are being given broader functions. Since changes of this type are usually made voluntarily in an effort to improve the whole industrial relations set-up, they may prove of more lasting value than the new collective bargaining techniques, so often adopted reluctantly and in an atmosphere of hostility.

When the Labor Relations Act was passed in 1935 many companies had wellrounded industrial relations programs administered by special departments; a much larger number, however, conducted personnel matters in a more or less routine manner without the guidance of definite policies or the technical aid of trained staffs. It is obvious that the effect of the measure on the two types of companies would be quite different, just as it would vary from company to company, depending on the success with which the employer-employee relationships had been handled in the past. Naturally also the companies that previously had given little thought to industrial relations have found it most necessary since the passage of the Act to make changes in their methods and in their whole approach.

One of the chief changes has to do with the formulation and announcement of labor policies. Until quite recently the traditional attitude of most employers was that their labor policies concerned no one but themselves and that there was no need for putting them in writing even for use within the company. Typical of this point of view is the statement of the chief executive of a nationally known business organization who, when pressed to formulate and state his labor policies, replied that "every time you put anything about labor in writing you start trouble." Another

-A.B., I916, Monmouth College; Ph.D., I922, Johns Hopkins University. Staff member, Industrial Relations Counselors, Inc. Personnel manager, Bayonne Works, Standard Oil Company of New Jersey, r922-r930; Director of industrial relations, Colonial Beacon Oil Company, r930-r935. 
executive flatly refused to put his labor policies in writing on the grounds that if he did so he and his executives would be committed to making them effective.

Many employers of this type have now come to realize that it is a good thing for employees to know what they can count on from their own employer and that management is benefited by the process of "critical evaluation which must precede any formulation of labor policy. Frequently it is only when faced with the actual task of putting his labor policies down in writing that an employer realizes the bankruptcy of his labor program. For these reasons a veritable stream of company labor policies, most of them clear and comprehensive, has appeared in the last few years. The benefits in terms of mutual understanding and improved employer-employee relationships have been clearly demonstrated. Final evidence of the trend in this direction is found in the "Statement on Employment Relations" and the outline of "Employment Procedures" adopted by the National Association of Manufacturers at the Congress of American Industry held in New York on December 9, 1937. The Congress' Platform for American Industry endorsed the provision of "a sound and well defined labor policy suitable to the problems of the particular company, community and industry. Such a policy should provide for the free interchange of ideas between management and its employees on all matters of mutual interest, adequate opportunity for the consideration and adjustment of all complaints, maintenance of good working conditions and fair wages for the work performed."

Hiring policies and procedures also have been influenced by the Wagner Act in several important respects. The employment officers of companies without union agreements are taking greater pains to see that new employees are fully informed as to the wages and working conditions pertaining to the job and as to rights and privileges under the labor policies of the company. Numerous companies which in the past did not hesitate to look into the union affiliations of applicants wisely have abandoned this practice and have cautioned employment departments against making such inquiries or differentiating among applicants on this basis. Companies which operate under union agreements are confronted with somewhat different problems. Although most agreements state that the employer retains the authority to reject unsatisfactory applicants, his insistence on this right may provoke a dispute with the union or stoppage of work. Some employers who have recently been compelled to hire through union halls or headquarters contend that selection standards have been lowered and that it has been difficult to maintain adequate employment procedures. Such conditions may arise from the unfamiliarity of both parties with the new method, since in the garment industries, for example, the unions have operated central employment offices successfully for many years. In fact under many of the recent agreements, employment standards are being maintained by the absolute elimination of favoritism and discrimination and the endeavor on the part of both the employment office and the supervisory force to secure the active co-operation of the union.

One of the most effective provisions of the Wagner. Act has been the, one that 
makes it an unfair labor practice to discharge an employee for belonging to a labor union. Employers quite generally have altered their personnel procedures so as to give increased protection to workers in all cases of discharge. Recognizing the possibility that any dismissal for cause, regardless of its basis, may be challenged as an unfair practice, employers have taken various steps to assure themselves of the facts of each case and to guard against unwarranted action by their subordinates. Some of the principal revisions of discharge policy and procedure are, ( $I$ ) announcing the causes for which employees will be discharged, (2) provision for advance notice or warning to an employee before discharging him, (3) limitation of the authority of the foremen to fire until after review by higher executives of the company, (4) granting of the right of appeal and a hearing, and (5) the exit interview, whereby employees being dismissed are not permitted to collect their pay until they have been interviewed by an employment officer.

On the whole it may, be said that the Wagner Act has resulted in a marked improvement in personnel practices connected with discharges and has contributed substantially to the security of wage earners by placing a curb on autocratic action by local managements and supervisory forces and by reinforcing the efforts of personnel men to see that fair treatment is accorded.

It has long been customary for the more progressive companies to provide definite lines of promotion and to base layoffs and re-employment on such factors as ability, length of service in the company or department, potential value to the organization and, in some cases, number of dependents. In the great majority of companies, however, promotions and layoffs were left largely to subordinate executives or supervisory forces without the guidance of set policies or provision for review to prevent errors and injustices.

Now that all labor policies are being brought under scrutiny, there is a tendency to revise methods of layoff and promotion as well as the techniques connected with discharges. This is less true in companies where in the past management decisions with respect to these matters have been fair, and employees, therefore, have no reason to object to them. Ability in such concerns remains the major consideration in determining decisions, although frequently if all other things are equal the service factor governs. This kind of a seniority policy promotes rather than impedes the development of employee efficiency. Among companies with little industrial relations experience, however, there has been a distinct trend toward making seniority alone the basis of layoffs and, often, of promotions as well. While from the standpoint of the worker this policy represents a considerable improvement over the arrangements that formerly predominated, it throws a greater burden upon the personnel office and the supervisors if the caliber of the working force is not to suffer.

The need for grading up the entire work force that has been created by the action of these new forces undoubtedly explains the significant increase of rating systems and periodic salary reviews. More employers than ever, impressed with the need of holding greater opportunities before their employees, are preparing and posting 
charts of lines of promotion. Initial selection is being conducted more critically; higher standards of employment are being set; and there is greater insistence that the incompetent be culled out in the early stages of employment. These are matters for the attention not only of the personnel staff but of the foremen, superintendents and department heads upon whom the responsibility for this phase of personnel work must rest. Competent supervisors aided by an able personnel staff should find it possible to maintain management's right to consider merit and potential ability whenever clearly essential to the well-being of the business.

An outstanding development in personnel administration has been the effect of the Wagner Act upon the functions of the supervisory force. The earlier discussion has indicated that the powers of supervisors have been curbed in numerous respects as the result of the Act. At the same time there has come to be an increasing realization among personnel men and business executives that if any program of industrial relations is to function successfully, the foreman must play an important part. The strategic position of the foreman or straw boss with respect to employee relations and the extent to which his job involves personnel functions have been well outlined by Robert N. McMurry, executive director of the Psychological Corporation of Chicago.

In actual practice these straw bosses perform important and comprehensive personnel functions. They must exercise judgment, and frequently have the final decision in the following matters:

r. The actual selection or final approval of persons to be hired for their departments.

2. The training and job direction of these new people after they have been assigned.

3. The rating and measuring of job performance.

4. Discipline and corrective work, including interviews.

5. The creation of the proper employe attitudes toward the job and toward the management.

6. Determination of rates of compensation.

7. Determination of length of work in the course of a week.

8. Decisions concerning promotion and the creation of a reserve of promotable material.

9. Decisions relative to employe complaints and grievances, and handling of "problem" employes.

10. Determination of the persons to be laid off in slack times or dismissed for ineffciency or other reasons. Often in connection with this work these straw bosses handle the dismissal interview. ${ }^{1}$

What has been said above emphasizes the tremendous significance that preparation of the executive and supervisory force to discharge their responsibilities has under the new conditions. The urgency of this problem is well expressed in the summary to Mr. McMurry's article.

Employe-employer relations at the straw-boss and foreman level must be watched carefully by management, for at that level human relations are almost inseparable from the job. It is through the immediate superior at that level that contact is established between the workmen and management. It is at that point of contact that actual experiences and

${ }^{2}$ MeMurty, So You Handle Peoplel, (Nov. 1937) 2 Society for Advancendent of Management J., 168. 
impressions occur. It is necessary therefore to train executives of this first outpost of management in the fundamentals of good industrial relations policies and practices, for they occupy the diplomatic post of management and, as such, are the moulders of worker opinion. ${ }^{2}$

Foreman training is an aspect of personnel administration about which there has been more talk and less action than nearly any other. The oldest forms of organized activity in history, the army and the navy, have long ago recognized the vital importance of the training of officers, and industry might well take a leaf from their book of experience. The personnel profession itself is none too well equipped to guide and assist American management in this function. Many employers have turned to motion pictures, still pictures, lectures from university extension departments and commercially prepared courses for foreman conferences. While such devices are probably better than nothing at all, they do not represent the best approach to this problem. Too many programs of foreman training have been spasmodic, limited to a series of six or a dozen meetings on very general topics or to a course in so-called "worker psychology." Both employers and personnel men would do well to give more serious consideration to the development of more effective methods of foreman training with a view to making it an integral and continuing part of the management process.

It may be concluded that in a host of companies the Wagner Act has compelled the cessation of unfair, shortsighted labor practices and has offered the employees for the first time a certain degree of protection and security in their employment. Even companies with fairly well developed industrial relations programs have been stimulated in many instances to reconsider their policies and procedures and to change them beneficially at certain points.

Another and less fortunate aspect of the Act's operation appears when the effect on companies with long-established and successful personnel programs is considered. These companies in shaping their policies proceeded on the theory that for employer and employees the spheres of common interest were far greater than those of conflict. Emphasis was placed on collective dealing rather than collective bargaining. In varying degree managements took the initiative in introducing benefit plans, shortening hours and raising wages, and the constitutions of certain employee representation plans gave the members broad powers with respect to such basic relationships.

The Labor Relations Act by its concentration on collective bargaining and organization has brought concepts of struggle and economic warfare to the fore. Too often fair employers have been discredited and the peaceful and mutually beneficial association of employers and employees of many years standing has been cited as evidence of illegal domination and coercion of employees. Many employees, confused by the intent of the Act, are afraid to approach their employers, and employers are uncertain as to where friendly contact leaves off and improper influence begins. A legalistic approach threatens to pervade industrial relations; both employees and

'Ibid. 
employers are tremendously concerned with legal counsel, labor board hearings, injunctions, court decisions and the complexities arising from jurisdictional disputes. Employers of limited vision have shown a tendency to shape their personnel programs either according to the strict requirements of law or the minimum stipulated in union agreements, taking the position that employees must depend on what they can get from legislation or collective bargaining.

There is already some promise, however, that the concerns which have long been looked to as leaders in industrial relations have oriented themselves in the new situation and realize that despite the confusion induced by the law they must continue to strive for smooth-working organizations and to maintain personnel policies which will promote stability in the labor force and attract efficient workers. The accomplishment of these ends is the most important function of present-day personnel departments. Neither companies nor employee organizations in the long run can prosper on a basis of mutual suspicion, hostility and economic warfare. The most effective approach to this whole problem lies in the increased application of sound personnel policies. By reason of his position, the responsibility for taking the initiative rests with the employer. As Henry L. McCarthy, for a time regional director of the Tenth District Labor Relations Board, said:

... there is only one basic cause for labor troubles, and that is poor administration of personnel. No employer who has developed and maintained an intelligent program of personnel administration has ever been hailed before the labor board. Further than that, such employers do not have labor troubles nor do they have to worry about the so-called labor agitator. Their battle is won before they start. ${ }^{3}$

$$
\text { p. } \mathbf{~ I I ~}
$$

'MeCarthy, Industrial Relations and the Labor Board, Employe Rezatzons, Bull. No. 3, June, 1935, 